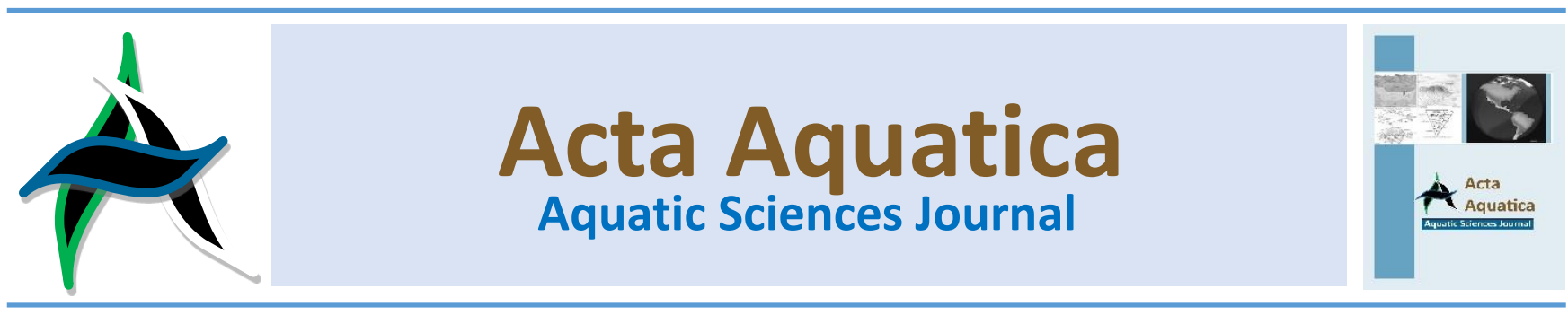

\title{
The influence of the mangrove leaves infusion Excoecaria agallocha against Aeromonas hydrophila bacteria infection in tilapia
}

\section{Pengaruh infusa daun mangrove Excoecaria agallocha terhadap infeksi bakteri Aeromonas hydrophila pada ikan nila}

\author{
Dian Puspitasari ${ }^{a, *}$ dan Desrita ${ }^{b}$ \\ a Department of Aquaculture, Asahan University, Indonesia \\ ${ }^{\mathrm{b}}$ Department of Aquatic Resources Management, Sumatera Utara University, Indonesia
}

\begin{abstract}
Tilapia is fish consumption with some excess, that is has a high protein, non-cholesterol, the taste is delicious, affordable and easily cultivated. One of the problems in cultivating them is a disease because it can cause the death of the fish. Diseasecausing factors can be derived from the bacterium Aeromonas hydrophila. The bacteria $A$. hydrophila can cause the death of fish until $80 \%-100 \%$ within 1-2 week and even many that are already resistant to several types of commercial antibiotics, so that the need to look for a new antibiotics source. The source of these antibiotics can be derived from nature because it is cheaper, safer and environmentally friendly. Mangrove Excoecaria agallocha has been known to have potential as an antibacterial, larvacide, and antifungal. This can be used as a source of antibiotics. The purpose of this research is to analyze the potential of the mangrove leaves infusion E. agallocha in preventing the spread of disease in tilapia infected the bacteria and identify the compounds of secondary metabolite. This research was carried out from March-August 2018 and use approach posttest-only control group design (by comparing the treatment with the control group). The amount of treatment is five with three replicates. The dose used, namely $0 \%, 2.5 \%, 5 \%$, $7.5 \%$ and $10 \%$. The results showed that there was no difference in the influence of the mangrove leaves infusion E. agallocha against weight gain and survival rate of tilapia juveniles. The result of phytochemical screening indicates that $E$. agallocha leaves infusion contains tannins and flavonoids.
\end{abstract}

Keywords: Excoecaria agallocha; phytochemical; tilapia

\begin{abstract}
Abstrak
Ikan nila merupakan ikan konsumsi dengan beberapa kelebihan yaitu memiliki kandungan protein yang tinggi, non-kolesterol, rasa enak, harga terjangkau dan mudah dibudidayakan. Salah satu masalah yang dihadapi dalam membudidayakannya adalah penyakit, karena dapat menyebabkan kematian pada ikan. Faktor penyebab penyakit dapat berasal dari golongan bakteri yaitu Aeromonas hydrophila. Bakteri A. hydrophila dapat menyebabkan kematian ikan dengan kisaran $80 \%-100 \%$ dalam jangka waktu 1-2 minggu dan bahkan banyak yang sudah resisten terhadap beberapa jenis antibiotik komersil sehingga perlu dicari sumber antibiotik baru. Sumber antibiotik tersebut dapat berasal dari alam karena lebih murah, aman dan ramah lingkungan. Mangrove jenis Excoecaria agallocha telah diketahui memiliki potensi sebagai antibakteri. Hal ini dapat dijadikan referensi sebagai bahan antibiotik baru. Tujuan dari penelitian ini adalah menganalisa potensi infusa daun mangrove jenis $E$. agallocha dalam mencegah penyebaran penyakit pada Ikan Nila yang terinfeksi bakteri dan mengidentifikasi kandungan golongan senyawa metabolit sekundernya. Penelitian ini dilaksanakan dari bulan Maret - Agustus 2018. Penelitian ini menggunakan pendekatan posttest only control group design (dengan membandingkan antara kelompok perlakuan dengan kelompok kontrol). Jumlah perlakuan adalah 5 dengan 3 kali ulangan. Dosis yang digunakan yaitu 0\%, 2,5\%, $5 \%$, 7,5\% dan $10 \%$. Hasil penelitian menunjukkan bahwa tidak terdapat perbedaan pengaruh infusa daun mangrove jenis $E$. agallocha terhadap bobot tubuh dan kelangsungan hidup dari benih Ikan Nila. Hasil skrining fitokimia menunjukkan bahwa pada infusa daun $E$. agallocha mengandung senyawa tanin dan flavonoid.
\end{abstract}

\footnotetext{
* Corresponding author: Department of Aquaculture, Asahan University, Jalan Jend. Ahmad Yani, Kisaran, Asahan, Sumatera Utara. Indonesia. 21216. Telp. 0623.62342643.

email: di.dianri@yahoo.com

doi: https://doi.org/10.29103/aa.v6i1.1064
} 


\section{Introduction}

Tilapia (Oreochromis niloticus) is one of the results of freshwater fish farming. Excess which owned tilapia is tasty, solid flesh, not having many spines, easily obtained, and the price is relatively low. This fish is easily cultivated and able to live until the height of the $500 \mathrm{~m}$ above sea level (Ardita et al., 2015).

One of the constraints in cultivating tilapia is a disease caused by bacteria. One example of a disease-causing bacterium is Aeromonas hydrophila. These bacteria can cause mortality of fish $80 \%-100 \%$ with a period of 1-2 the week (Sari et al., 2012). The giving of drugs such as antibiotics is considered the most effective way and quickly in coping the disease in fish. Using antibiotics continuously can cause negative effects, such as the occurrence of bacterial resistance, and the price is high. One type of disease-causing bacteria on the fish is A. hydrophila. The results showed the presence of bacterial resistance of $A$. hydrophila against some antibiotics such as amoxicillin, ampicillin, at lincomycin, novobiocin, oxacillin, penicillin, combinations with sulfamethoxazole, trimethoprim and rifampicin (Herawati et al., 2013).

The selected solution by finding other materials derived from nature that has potential as an antibiotic. Mangrove $E$. agallocha has been known to have a variety benefits to human interests, among others, the leaves have potential as larvacide, antibacterial, and antifungal (Agoramoorthy et al., 2007; Dhayanithi et al., 2012; Rajeswari \& Rao, 2015). The active ingredient of leaves of mangrove E. agallocha, which has potential as an antibacterial, i.e. lupeol (Dawane \& Fulekal, 2017). Information about the benefits of the leaf of mangrove $E$. agallocha as test in-vivo in tilapia against $A$. hydrophila is limited. The purpose of this research includes: analyze potential infusion leaf of mangrove $E$. agallocha in tilapia which infected by $A$. hydrophila and identify active compounds infusion leaf of mangrove E. agallocha.

\section{Material and method}

This research was carried out from March until August 2018 and use approach posttest-only control group design (by comparing the treatment with the control group) (Kasjono \& Yasril, 2009). The design of this research is Complete Random Design, with five treatments and three replicates. The doses of each treatment are $0 \%, 2.5 \%, 5 \%, 7.5 \%$ and $10 \%$.

\subsection{Preparation}

The fish used in the research was tilapia juveniles with a length of $8-10 \mathrm{~cm}$. Fish used was adapted in a plastic box for seven days and given aeration. The sample of mangrove leaves E. agallocha taken from mangrove vegetation at Bunga Beach, Batu Bara regency.

\subsection{Making of leaf infusion of mangrove E. agallocha}

The mangrove leaves $E$. agallocha cleaned using water. After that, continued with the drying process and then mashed. The leaves dried of mangrove $E$ agallocha boiled at a temperature of $90{ }^{\circ} \mathrm{C}$ for 15 minutes. The filtering is done by using fabric flannel (infusion 10\%) (DepKes, 2000).

\subsection{Test of the mangrove leaves infusion E. agallocha}

Inoculum A. hydrophila bacteria made on Nutrient Broth media (NB) with a density of $1 \times 10^{8} \mathrm{CFU} / \mathrm{mL}$ (Indriani et al., 2014). Tilapia juveniles injected A. Hydrophila bacteria with a dose of $0.1 \mathrm{~mL}$ on the intramuscular. The mangrove leaves infusion $E$. agallocha mixed with fish feed after infected bacteria a. hydrophila. Feeding rate of $5 \%$ of the weight and given as much as three times, i.e. morning (07.00-08.00 am), noon (12.00 -01.00 $\mathrm{pm}$ ) and evening (5.00-6.00 pm). The period of observation is 14 days.

\subsection{Water quality parameters}

Water quality parameters measured in this study such as dissolved oxygen (DO), $\mathrm{pH}$ and temperature.

\subsection{Weight gain}

The formula to calculate weight gain is:

Weight gain: Mean Final Weight -Mean Initial Weight

(Debnath et al., 2017)

\subsection{Survival rate}

The formula to calculate the survival rate is:

$$
\text { Survival rate }(\%)=\frac{\text { No.of Fish Caught }}{\text { No.of Fish Release }} \times 100
$$

(Debnath et al., 2017)

\subsection{Phytochemical analysis}

The phytochemical analysis is used to analyze the mangrove leaves infusion of E. agallocha. The test is including alkaloids, flavonoids, tannins, saponins, test test test these Terpenoids and steroids.

\subsection{Statistical analysis}

The research results including weight gain, survival rate and phytochemical screening of the mangrove leave infusion $E$. agallocha. Weight gain and survival rate data of tilapia juveniles were analyzed using statistical analysis. Phytochemical screening data of the mangrove leaves infusion E. agallocha is analyzed descriptively.

\section{Result and discussion}

\subsection{Result}

\subsubsection{Weight gain of tilapia juveniles}

The graph of the weight gain tilapia juveniles in Figure 1 and the results of the statistical analysis of the weight gain tilapia juveniles in Table 1.

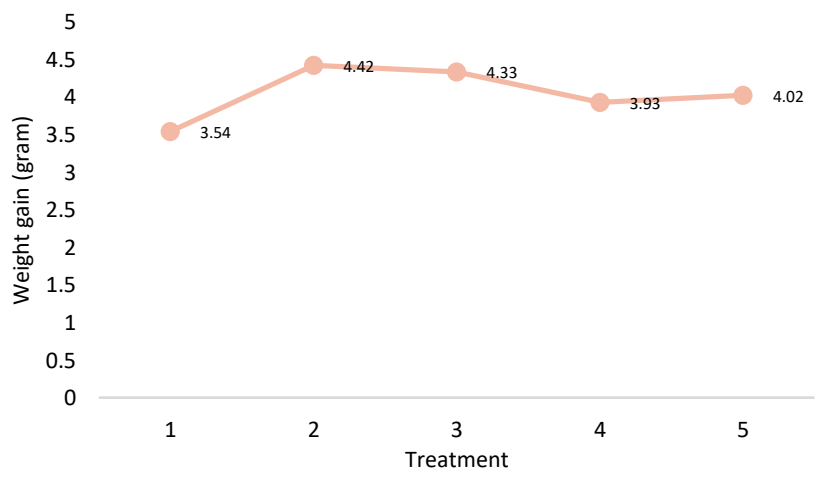

Figure 1. Weight gain of tilapia juveniles. 
Figure 1 shows no differences in weight gain tilapia juveniles when compared with control. Tilapia juveniles weight gain has decreased during the 14-day observation.

Table 1

The results of weight gain statistical analysis.

\begin{tabular}{lccccc}
\hline & $\begin{array}{c}\text { Sum of } \\
\text { squares }\end{array}$ & df & Mean square & $\mathrm{F}$ & Sig. \\
\hline $\begin{array}{l}\text { Between } \\
\text { groups }\end{array}$ & .784 & 4 & .196 & .056 & .993 \\
Within groups & 35.229 & 10 & 3.523 & & \\
Total & 36.013 & 14 & & & \\
\hline
\end{tabular}

Table 1 is a result of weight gain statistical analysis in tilapia juveniles. The results of the statistical analysis showed that there is no influence of granting mangrove leaves infusion $E$. agallocha against weight gain of tilapia juveniles. The active compound of mangrove leaves infusion $E$. agallocha is not increasing the weight gain of the tilapia juveniles.

\subsubsection{The survival rate of tilapia juveniles}

Observation of survival rate tilapia juveniles performed for 14 days. Observations survival rate of tilapia juveniles in Figure 2 and the results of statistical analysis survival rate of tilapia juveniles in table 2 .

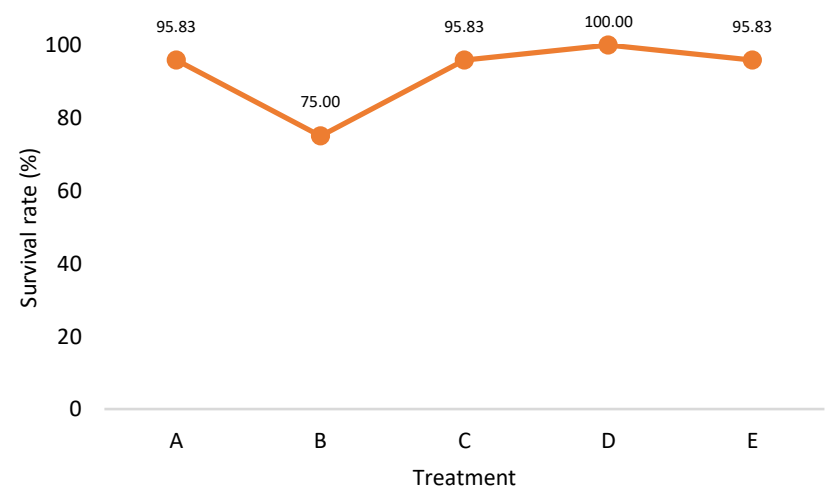

Figure 2. Survival rate of tilapia juveniles

The results observation of survival rate tilapia juveniles, shown in Figure 2. Figure 2 indicates that survival rate at the treatment $D(100 \%)$ higher than the control or treatment $A$ (95.83\%). The lowest result is treatment B (75\%).

Table 2

The results of a statistical analysis of survival rate tilapia juveniles.

\begin{tabular}{lccccc}
\hline & $\begin{array}{c}\text { Sum of } \\
\text { squares }\end{array}$ & df & Mean square & $F$ & Sig. \\
\hline $\begin{array}{l}\text { Between } \\
\text { groups }\end{array}$ & 7.600 & 4 & 1.900 & 1.188 & .374 \\
Within groups & 16.000 & 10 & 1.600 & & \\
Total & 23.600 & 14 & & & \\
\hline
\end{tabular}

The results of a statistical analysis of survival rate of tilapia juveniles represent in table 2 . Table 2 shows that the value of $P>0.05$. The results statistical analysis demonstrate that granting mangrove leaves infusion $E$. agallocha did not affect the survival rate of tilapia juveniles.

\subsubsection{Water quality parameters}

Water quality parameters include temperature, $\mathrm{pH}$ and DO. The result of the observation of water quality parameters can see in Table 3.

Table 3

The results of water quality parameters.

\begin{tabular}{cccc}
\hline Treatment & Temperature $\left({ }^{\circ} \mathrm{C}\right)$ & $\mathrm{Ph}$ & $\mathrm{DO}(\mathrm{mg} / \mathrm{L})$ \\
\hline A & $28,2-30,8$ & $7,2-8,44$ & $4,32-7,73$ \\
B & $28,2-30,8$ & $7,3-8,39$ & $4,65-7,02$ \\
C & $28,2-30,8$ & $7,1-8,37$ & $4,51-5,61$ \\
D & $28,2-31,5$ & $7,1-8,46$ & $4,03-5,07$ \\
E & $28,1-31,0$ & $6,9-8,36$ & $4,12-6,43$ \\
\hline
\end{tabular}

The results measurement of water quality parameters in Table 3. The lowest temperature was obtained based on measurement results of $28,1^{\circ} \mathrm{C}$, while the highest temperature of $31,5^{\circ} \mathrm{C}$. The lowest $\mathrm{pH}$ value of 6,9 and the highest $\mathrm{pH}$ value amounted to 8,46 . The results measurement of DO indicates that the lowest value of $4,03 \mathrm{mg} / \mathrm{L}$ and the highest grade of $7,73 \mathrm{mg} / \mathrm{L}$.

\subsubsection{Phytochemical screening}

Phytochemical screening in mangrove leaves infusion $E$. agallocha include flavonoids, alkaloids, terpenoids, tannins, saponins, and steroid. The results of the phytochemical screening can see in table 4 .

Table 4

The result of phytochemical screening.

\begin{tabular}{lcc}
\hline \multicolumn{1}{c}{ Name } & Result & Description \\
\hline Flavonoids & + & Detected \\
Alkaloids & - & Not Detected \\
Terpenoids & - & Not Detected \\
Steroid & - & Not Detected \\
Tannins & + & Detected \\
Saponins & - & Not Detected \\
\hline
\end{tabular}

Phytochemical screening in the mangrove leaves infusion E. agallocha to contain tannin and flavonoid. The other compounds, such as alkaloids, Terpenoids, steroids, and saponins, are not detected in the mangrove leaves infusion $E$. agallocha.

\subsection{Discussion}

\subsubsection{Weight gain of tilapia juveniles}

Phytochemical screening shows that the active compound from the mangrove leaves infusion $E$. agallocha showed the presence of tannins and flavonoids. Tannin allegedly is the cause of the existence of a decrease in body weight of seed fish tilapia. Pangesti et al. (2016), stated that tannin has a role in lowering the weight of the body, the digestibility and efficiency of feed consumed. Tannins can injure the digestive, so it causes disruption the functions of the digestive tilapia juveniles. The compounds contained in the tannin which binding proteins, causing feed becomes difficult to digest. The same thing is expressed by Wie Lawa and Lazarus (2015) if tannins have properties that can be bound to a protein feed so that it forms a complex bond that is difficultly soluble in water, causing turbidity, and inhibits the enzymes work in the body.

\subsubsection{The survival rate of tilapia juveniles}

The results of phytochemical screening show that mangrove leaves infusion $E$. agallocha contain flavonoids and 
tannins. Flavonoids and tannins are known to have many benefits. Flavonoids have a role as an immunostimulant that can prevent against infection that goes into the body (Abror et al., 2018), antioxidants (Prameswari \& Widjanarko, 2014), and antibacterial (Rosidah \& Afizia, 2012). The potential of tannin, among other antibacterials (Setyawan, 2015), antioxidants (Prameswari \& Widjanarko, 2014), and antibacterial (Rosidah \& Afizia, 2012). However, the potency of flavonoids and tannins are not to see in the survival rate of tilapia juveniles. The dose of tannin and flavonoid contained in mangrove leaves infusion $E$. agallocha is allegedly still low, and the time of observation is less long.

The value of the survival rate between the treatment does not show different results, where the value is above $70 \%$ and achieving $100 \%$. Tilapia juveniles infected $A$. hydrophila bacteria can survive; this is alleged because of a good environment. Tantu et al. (2013), state that good environmental control in aquaculture can prevent the spread of the disease. The spread of the disease in aquaculture can be prevented by the water quality maintained, and also, the quantity and quality of feed is a part of the efforts of disease prevention.

\subsubsection{Water quality parameters}

Water quality is one of the factors that an important in the life of the fish. Water quality parameters include temperature, $\mathrm{pH}$ and $\mathrm{DO}$ (dissolve oxygen). The temperature affects the appetite of fish. Appetite fish increased simultaneously with the increase in temperature. The temperature decrease has an effect on the digestive process in the body of the fish and metabolism process will run slower. The $\mathrm{pH}$ value can disrupt the lives of fish if $\mathrm{pH}$ values in the water that are too low (very acidic) and too high (highly alkaline). Dissolve Oxygen (DO) is required by fish to respiration, metabolism and maintain his life (Effendi, 2003).

The results of measurements of water temperature are $28.1{ }^{\circ} \mathrm{C}-31.5^{\circ} \mathrm{C}$. The $\mathrm{pH}$ measured ranged from $6.9-8.46$, while the range measurement results of DO is $4.03 \mathrm{mg} / \mathrm{L}-7.73 \mathrm{mg} / \mathrm{L}$. The range values of the water quality measurement are still in the normal range, as the value of water quality issued by the Badan Standardisasi Nasional (2009), the temperature $\left(25^{\circ} \mathrm{C}-32\right.$ $\left.{ }^{\circ} \mathrm{C}\right), \mathrm{pH}(6.5-8.5)$ and $\mathrm{DO}(\geq 3 \mathrm{mg} / \mathrm{L})$.

Kordi and Tancung (2007), state that $\mathrm{pH}$ value in aquaculture in the range $6,5-9$. The ranges optimal temperature for aquaculture between $28{ }^{\circ} \mathrm{C}-32{ }^{\circ} \mathrm{C}$. Certain types of fish can survive with the DO (dissolve oxygen) value $3 \mathrm{mg} / \mathrm{L}$. Dissolve oxygen with a value below $4 \mathrm{mg} / \mathrm{L}$, would cause a decrease in appetite fish, although the fish can still survive.

\subsubsection{Phytochemical screening}

Metabolites secondary of the mangrove leaves infusion E. agallocha based on the results of the phytochemical screening, namely flavonoids and tannins. Some researchers state that the mangrove leaf E. agallocha contains flavonoids (Patra, 2009, Kumar et al., 2013) and tannins (Patra, 2009; Kumar et al., 2013; Kaliamurthi \& Selvaraj, 2016).

\section{Conclusion}

The research showed that there was no difference in the influence of the mangrove leaves infusion $E$. agallocha against weight gain and survival rate of tilapia juveniles. The result of phytochemical screening indicates that E. agallocha leaves infusion contains tannins and flavonoids.

\section{Acknowledgements}

The authors would like to thanks to Aquaculture laboratory Asahan University, Agrotechnology laboratory Asahan University, Chemical Laboratory Sumatera Utara University, Ministry of Research Technology and Higher Education of the Republic of Indonesia, Indonesia Fisheries Quarantine Service for their continuous support in making this research a success.

\section{Bibliografi}

Abror, Y.K., E.D. Woelansari, Suhariyadi, 2018. Imunomodulator Ekstrak Etanol Daun Mimba (Azadirachta indica) terhadap Jumlah Sel Makrofag Peritoneal pada Mencit yang Diinduksi Vaksin BCG. J. Teknologi Laboratorium, 8 (1): 8-14.

Agoramoorthy, G., M. Chandrasekaran, V. Venkatesalu dan M.J. Hsu. 2007. Antibacterial and Antifungal Activities of Fatty Acid Methyl Esters of the Blind-your-eye Mangrove from India. Brazillian Journal of Microbiology, 38:739-742.

Ardita, N., A. Budiharjo, Sari, S.L.A., 2015. Pertumbuhan dan Rasio Konversi Pakan Ikan Nila (Oreochromis niloticus) dengan Penambahan Prebiotik. Bioteknologi, 12 (1): 1621.

Badan Standarisasi Nasional (SNI 7550), 2009. Produksi Ikan Nila (Oreochromis niloticus Bleeker) Kelas Pembesaran di Kolam Air Tenang.

Dawane, V., Fulekar, M.H., 2017. Quantification ol Lupeol In Excoecaria agallocha Leaf, Stem and Root by HPTLC. Int Res. J. Biological S.ci., 6 (1) : 1-5.

Debnath, P., S. K. Chowdhury, Roy, N. C., 2017. Effect of Dietary Slat Supplementation on Growth and Feed Utilization of Tilapia (Oreochromis niloticus). International J. of Fisheries and Aquatic Studies, 5(6): 275-280.

Departemen Kesehatan RI, 2000. Parameter Standar Umum Ekstrak Tumbuhan Obat. Departemen Kesehatan : Jakarta. HIm. 5-6.

Dhayanithi N. M., T. T. A Kumar, Balasubramanian, T., 2012. Effect of Excoecaria agallocha Leaves Against Aeromonas hydrophila in Marine Ornamental Fish, Amphiprion sebae. Indian J. Mar.Sci., 41 (1): 76-82.

Effendi, H., 2003. Telaah Kualitas Air, Bagi Pengelolaan Sumber Daya dan Lingkungan Perairan. Kanisius. Yogyakarta.

Herawati, N. M., H. Mahatmi, Besung, I.N.K., 2013. Resistensi Bakteri Aeromonas sp. Isolat Ikan Piranha (Pygosentrus nattereri) Bali Safari and Marine Park Terhadap Antibiotik. Jurnal IImu dan Kesehatan Hewan., 1 (2) : 5256.

Kaliamurthi , S., Selvaraj, G., 2016. Insight on Excoecaria agallocha : An Overview. Nat Prod Chem Res., 4(2): 1-6.

Kasjono, H. S., Yasril, 2009. Teknik Sampling Untuk Penelitian Kesehatan. Graha IImu. Yogyakarta.

Kordi, M.G.H., Tancung, A.B., 2007. Pengelolaan Kualitas Air. PT Rineka Cipta. Jakarta. 
Kumar, S.S., P. Sen, Anbuselvi, S., 2013. Preliminary Analysis of Excoecaria agallocha and Avicennia. BioMedRx., 1(4): 371-373.

Pangesti, U.T., M. Halim Natsir, Sudjarwo, E., 2016. Pengaruh Penggunaan Tepung Biji Nangka (Artocarpus heterophyllus) dalam Pakan Terhadap Bobot Giblet Ayam Pedaging. J. Ternak Tropika, 17(2): 58-65.

Prameswari, O.M., Widjanarko, S.B., 2014. Uji Efek Ekstrak Air Daun Pandan Wangi Terhadap Penurunan Kadar Glukosa Darah dan Histopatologi Tikus Diabetes Mellitus. J. Pangan dan Agroindustri, 2 (2): 16-27.

Rajeswari, K., Bhaskara-Rao, T., 2015. Excoecaria agallocha Linn (Euphrobiaceae): An overview. J. Chem. Pharm. Res., 7 (10): 423-439.

Rosidah, Afizia, W. M., 2012. Potensi Ekstrak Daun Jambu Biji Sebagai Antibakterial untuk Menanggulangi Serangan Bakteri Aeromonas hydrophila Pada Ikan Gurame (Osphronemus gouramy Lacepede). J. Akuatika, III (1): 19-27.

Patra, J.K., T. K. Panigrahi, S. K. Rath, N. K. Dhal, Thatoi, H., 2009. Phytochemical Screening and Antimicrobial Assessment of Leaf Extracts of Excoecaria agallocha L.: A Mangal Species of Bhitarkanika, Orissa, India. Adv. in Nat. Appl. Sci., 3(2): 241-246.

Sari, N.W., I. lukistyowati, Aryani, N., 2012. Pengaruh Pemberian Temulawak (Curcuma xanthorriza Roxb) Terhadap Kelulushidupan Ikan Mas (Cyprinus carpio L) Setelah Diinfeksi Aeromonas hydophila. Jurnal Perikanan dan Kelautan., 17 (2): 43-59.

Setyawan, A.B., 2015. Efektivitas Ekstrak Daun Kejibeling Untuk Meningkatkan Fagositosis Makrofag dan Produksi Roi Makrofag "Studi Eksperimental pada mencit Swiss yang Diinfeksi Staphylococcus aureus". J. Sains dan Kesehatan, 1. (4):195-201.

Tantu,W., R.A. Tumbol, Longdong, S.N.J., 2013. Deteksi Keberadaan Bakteri Aeromonas sp Pada Ikan Nila yang dibudidayakan di Karamba Jaring Apung Danau Tondano. J. Budidaya Perairan., 1(3): 74-80.

Wie Lawa, E. D., Lazarus, E. J. L., 2015. Suplementasi Tepung Ikan Terproteksi Ekstrak Tanin Hijauan Kabesak Kuning, Kabesak Hitam dan Kihujan dalam Ransum Terhadap Pertumbuhan Ternak Kambing. J. Zootek., 35 (2): 368 378. 